\title{
Perbandingan Metode Perhitungan Faktor Jam Puncak PDAM Tirta Rangga di Kecamatan Pabuaran - Kabupaten Subang
}

\author{
FRANSISKA YUSTIANA, WAHDAN NURFA AFANI MAULANA \\ Program Studi Teknik Sipil, Institut Teknologi Nasional Bandung, Indonesia \\ Email: fransiskayustiana2014@gmail.com
}

\begin{abstract}
ABSTRAK
Pola penggunaan air suatu daerah pemukiman berfluktuasi dan sangat bergantung pada ketersediaan air. Gaya hidup dan kondisi cuaca penyebab penggunaan air berfluktuasi. Penelitan ini bertujuan menentukan penggunaan air maksimum yaitu dengan menghitung faktor jam puncak maksimum, yang menjadi kriteria perencanaan jaringan distribusi air bersih. Perbandingan faktor jam puncak berdasarkan hasil Dari perhitungan beberapa metode, yaitu metode Red, Tricaricol, Briere, Martinez-solano, Diao dibandingkan dengan nilai faktor jam puncak yang dari Direktorat Jenderal Cipta Karya, yaitu faktor jam puncak sebesar 1,5 sedangkan faktor harian maksimum adalah 1,1. Nilai faktor jam puncak dipengaruhi oleh pola penggunaan air yang bervariasi menurut lokasinya, ketersediaan air bersih, perkiraan permintaan puncak dalam sistemnya. Faktor puncak dengan metode red merupakan metoda yang lebih akurat karena memiliki nilai faktor jam puncak 1,05 mendekati nilai faktor jam puncak yang ditetapkan Direktorat Jenderal Cipta Karya sebesar 1,5. Metoda Red dianggap dapat mengakomodir perencanaan instalasi penyediaan air di Indonesia, khususnya untuk daerah dengan ketersediaan air terbatas.
\end{abstract}

Kata kunci: faktor jam puncak, penggunaan air

\begin{abstract}
Water consumption always fluctuative in area will from time to time. Human activities change over time that make fluctuative water consumption. This study determine the maximum or peak water consumption rate by calculate the maximum peak faktor. Maximum peak faktor used to design a domestic water plant and domestic water distribution network. Maximum peak faktor value that determined by several methods such as the Red method, Tricaricol, Briere, Martinezsolano, Diao are compared to maximum peak faktor that establised by Direktorat Jenderal Cipta Karya (1.1 for maximum daily faktors and 1.5 for maximum peak faktors). Maximum peak faktor is effected by water consumption rate, life style, and fresh water supply. The Red method give more accurate result in determining maximum peak faktor. In this study, maximum peak faktor that determined by Red method is 1.05 approxt to maximum peak faktor of Direktorat Jenderal Cipta Karya 1.5. Maximum peak faktor that determined by Red method more appropriate to design domestic water supply and distribution instalation in any region in Indonesia that has less fresh water supply.
\end{abstract}

Keywords: maximum peak faktor, water consumption 


\section{PENDAHULUAN}

Penggunaan air suatu wilayah berfluktuasi tergantung pada pola penggunaan air dan berdasarkan musim. Pola penggunaan air yang berbeda tiap-tiap hari bahkan setiap jam ditentukan oleh gaya hidup dan perbedaan karakteristik suhu dan musim masing-masing wilayah. Fluktuasi penggunaan air adalah pola penggunaan air yang bervariasi dan tidak konstan oleh konsumen pada suatu wilayah. Kebiasaan dan aktivitas manusia merupakan penentu fluktuasi penggunaan air dalam satu hari. Faktor jam puncak maksimum merupakan volume tertinggi dari penggunaan air sehingga bisa menjadi kriteria perencanaan jaringan distribusi air bersih. Penelitian dilakukan di Kecamatan Pabuaran Kabupaten Subang ini menganalisis faktor jam puncak penggunaan air dari berbagai metode dan menganalisis produksi air yang dibutuhkan PDAM Tirta Rangga untuk mencukupi kebutuhan harian maksimum di daerah tersebut, yang kemudian didistribusikan ke seluruh pelanggan. Tujuan penelitian ini adalah menghitung faktor jam puncak dan mengetahui nilai faktor puncak dengan beberapa metode seperti Red, Briere, Martinez-solano, Diao, Dirjen Cipta Karya, CPHEEO dan membandingkannya dengan faktor jam puncak dari Direktorat Jenderal Cipta Karya.

\section{TINJAUAN PUSTAKA}

\subsection{Jenis Kegiatan Penggunaan Air}

Alokasi terbanyak penggunaan air domestik cenderung pada gelontor toilet atau kegiatan mandi. Tabel 1 menunjukkan urutan penggunaan air domestik dalam satu hari, baik di dalam rumah maupun kegiatan di luar rumah [5].

Tabel 1. Kegiatan dan Persentase Penggunaan Air

\begin{tabular}{clc} 
No. & \multicolumn{1}{|c}{ Kegiatan } & $\begin{array}{c}\text { Persentase Penggunaan Air } \\
{[\%]}\end{array}$ \\
\hline $\mathbf{1}$ & Gelontor toilet & 41 \\
\hline $\mathbf{2}$ & Mandi dan mencuci & 37 \\
\hline $\mathbf{3}$ & Kegiatan di dapur & 6 \\
\hline $\mathbf{4}$ & Air minum & 5 \\
\hline $\mathbf{5}$ & Mencuci pakaian & 4 \\
\hline $\mathbf{6}$ & Kebersihan rumah & 3 \\
\hline $\mathbf{7}$ & Menyiram tanaman & 3 \\
\hline $\mathbf{8}$ & Mencuci perabot keluarga & 1 \\
\hline
\end{tabular}

(Sumber: Poedjiastoeti, H., 2021)

\subsection{Pola Penggunaan Air}

Penggunaan air dalam satu hari dipilah kembali menjadi penggunaan air per jam. Hal ini dilakukan karena kebanyakan orang melakukan kegiatan yang menggunakan air hanya pada beberapa waktu tertentu. Pola tersebut akan menghasilkan penggunaan air maksimum pada jam tertentu. Hasil penelitian yang dilakukan oleh [6] di Amerika Serikat, menyajikan variasi penggunaan air pada jam-jam tertentu dalam satu hari. 
Tabel 2. Jam-Jam Puncak Penggunaan Air

\begin{tabular}{lc}
\hline \multicolumn{1}{c}{ Uraian } & Jam Penggunaan Air \\
\hline Penggunaan air minimum & $23: 00$ hingga 5:00 \\
\hline Penggunaan air maksimum & $\begin{array}{c}\text { 05:00 hingga 12:00 } \\
\text { (penggunaan air maksimum jam 07:00 hingga 08:00) }\end{array}$ \\
\hline Penggunaan air sedang & $12: 00$ hingga 17:00 \\
\hline Penggunaan air di malam hari & (penggunaan air maksimum jam 18:00 hingga 20:00) \\
\hline
\end{tabular}

(Sumber : Syahputra, B., 2020)

Penelitian lainnya tentang pemanfaatan air jam puncak yang dilakukan oleh [11] menyatakan penggunaan air pada jam puncak pada umumnya terjadi di pagi hari yaitu antara jam 06.00 sampai dengan jam 08.00. Penggunaan air maksimum di pagi hari terjadi akibat kegiatan mandi, memasak dan mencuci, baik mencuci piring maupun pakaian. Pada siang hari, penggunaan air maksimum terjadi akibat kegiatan ibadah sholat (berwudu), makan dan minum serta kegiatan di kamar kecil. Pada sore hari, kesibukan manusia kembali terjadi di dalam rumah. Penggunaan air pada sore hari didominasi kegiatan mandi, makan dan minum serta ibadah sholat (berwudu). Beberapa penduduk memiliki kebiasaan mencuci baju pada sore hari. Kegiatan di malam hari lebih sedikit sehingga penggunaan airnya juga akan lebih kecil dibandingkan waktu pagi hari hingga sore hari. Penggunaan air pada malam hari hanya ibadah sholat (berwudu) dan penggunaan kamar kecil. Beberapa orang memiliki kebiasaan merendam baju di malam hari tetapi akan dicuci pada pagi harinya.

\subsection{Faktor Puncak Direktorat Jenderal Cipta Karya (2000)}

Angka faktor jam puncak menurut [4] adalah 1,5. Angka ini selanjutkan dapat digunakan untuk menentukan atau merencanakan volume produksi air bersih pada instalasi penyedia air minum atau air domestik, seperti halnya PDAM, yang kemudian akan didistribusikan kepada para pelanggannya [4].

\subsection{Faktor Puncak Red, T. (1993)}

Angka faktor jam puncak adalah perbandingan antara debit maksimum selama waktu yang relatif singkat terhadap debit rata-rata selama periode pengamatan. Debit maksimum mewakili penggnuaan air selama periode saat jam puncak terjadi, atau debit yang paling tinggi dalam satu hari. Perhitungan faktor jam puncak maksimum dapat memerlukan data debit rata-rata, baik rata-rata dalam satu hari maupun dalam satu minggu. Angka faktor harian maksimun juga diperoleh dengan cara yang sama yaitu sesuai Persamaan 1 hingga Persamaan 3 berikut ini:

$$
\begin{aligned}
& Q_{r i}=\frac{Q_{h}}{7} \\
& f(\text { peak hour })=\frac{Q_{h m}}{Q_{r i}} \\
& f(\text { max day })=\frac{Q_{d m}}{Q_{r i}}
\end{aligned}
$$


dengan:

$Q_{r i} \quad=$ debit rata-rata harian dalam satu minggu,

$Q_{h} \quad=$ debit aliran per jam $\left[\mathrm{m}^{3} /\right.$ hari $]$,

$7 \quad=$ jumlah hari dalam satu minggu,

$f($ peak hour $)=$ angka faktor jam puncak,

$Q_{h m} \quad=$ debit maksimum dalam satu hari,

$f(\max$ day $)=$ angka faktor harian maksimum,

$Q_{d m} \quad=$ debit harian maksimum dalam satu minggu.

\subsection{Faktor Puncak Diao, et al. (2010)}

Diao, dkk menyajikan beberapa rumusan faktor puncak (Persamaan 4 hingga Persamaan 7) yang diturunkan oleh Asosiasi Teknis dan Ilmiah Jerman untuk Gas dan Air telah menyatakan keduanya permintaan hari puncak $\left(Q_{d}\right)$ dan permintaan jam puncak $\left(Q_{h}\right)$ tergantung pada populasi.

DVGW - Worksheet W400-1 (2004):

$$
\begin{aligned}
& P F_{d}=-0,1591 \cdot \ln E+3,5488 \\
& P F_{h}=-0,75 \cdot \ln E+11,679
\end{aligned}
$$

DVWG terbaru menyarankan hubungan berikut ini. DVGW - Worksheet W410 (2007):

$$
\begin{aligned}
& P F_{d}=3,9 \cdot E^{-0.0752} \\
& P F_{h}=18,1 \cdot E^{-0.1682}
\end{aligned}
$$

dengan:

$$
\begin{array}{ll}
P F_{d} & =\text { faktor puncak harian, } \\
P F_{h} & =\text { faktor jam puncak, } \\
E & =\text { jumlah konsumen atau pelanggan. }
\end{array}
$$

\subsection{Faktor Puncak Briere, F.G. (2007)}

[1] merujuk faktor puncak berdasarkan ukuran populasi, seperti yang diberikan oleh Pedoman Kementerian Lingkungan Ontario untuk desain fasilitas penyimpanan air, sistem distribusi air, sistem pembuangan limbah (Mei 1979), seperti disajikan pada Tabel 3 berikut.

Tabel 3. Faktor Puncak Untuk Laju Aliran Total Konsumsi Air

\begin{tabular}{ccc}
\hline Populasi & $\boldsymbol{P F}_{\boldsymbol{d}}$ & $\boldsymbol{P F}_{\boldsymbol{h}}$ \\
\hline Dibawah 500 & 3 & 4,5 \\
\hline 500 sampai 1.000 & 2,75 & 4,13 \\
\hline 1.001 sampai 2.000 & 2,5 & 3,75 \\
\hline 2.001 sampai 3.000 & 2,25 & 3,38 \\
\hline 3.001 sampai 10.000 & 2 & 3 \\
\hline 10.001 sampai 25.000 & 1,9 & 2,85 \\
\hline 25.000 sampai 50.000 & 1,8 & 2,7 \\
\hline 50.000 sampai 75.000 & 1,75 & 2,62 \\
\hline 75.001 sampai 150.000 & 1,65 & 2,48 \\
\hline Lebih dari 150.000 & 1,5 & 2,25
\end{tabular}

(Sumber : Scheepers, H.M., 2012) 


\subsection{Faktor Puncak Martinez-Solano (2008)}

[7] mengevaluasi faktor puncak melalui penuturan yang diperoleh melalui analisis statik konsumsi air, seperti yang ditunjukan pada Persamaan 8.

$$
\mathrm{PF}=\frac{17,12}{\sqrt{N}}+2,185
$$

dengan:

$N \quad$ = jumlah konsumen atau pelanggan.

\subsection{Faktor Puncak Dan Kebutuhan Air CPHEEO (1991)}

Di India, [2] telah merekomendasikan nilai faktor puncak berdasarkan populasi (Tabel 4) untuk desain sistem distribusi air.

Tabel 4. Nilai Faktor Puncak Berdasarkan Populasi

\begin{tabular}{cc}
\hline Populasi & Faktor Puncak \\
\hline Hingga 50.000 & 3,0 \\
\hline 50.000 sampai & 2,5 \\
\hline 200.000 & 2,0
\end{tabular}

(Sumber : Scheepers, H. M., 2012)

\subsection{Analisis Kebutuhan Air PDAM}

Perhitungan penggunaan air didasarkan pada kebutuhan air rata-rata, yaitu penggunaan air rata-rata harian dan penggunaan air harian maksimum. Total volume air yang dibutuhkan atau yang harus diproduksi oleh PDAM dihitung berdasarkan volume penggunaan air maksimum dan penggunaan air rata-rata setiap pelanggan kemudian ditambah dengan faktor kehilangan air akibat kebocoran selama proses distribusi. Total volume penggunaan air pelanggan akan dipakai menentuka volume atau kapasitas produksi PDAM, meliputi pemilihan sumber air, penentuan ketersediaan air dari sumber air terpilih, dan kemungkinan kebutuhan di masa yang akan dating. Volume produksi total PDAM kemudian akan dibagi sesuai jumlah hari untuk menghasilkan debit Rata-rata harian dan debit total. Berikut ini Persamaan 10 dan Persamaan 11 yang menghitung debit penggunaan air harian dan debit total.

Debit air bersih $\left(Q_{m d}\right)$

$$
Q_{m d}=P_{n} \times q \times f_{m d}
$$

Debit total produksi air bersih $\left(Q_{t}\right)$

$$
Q_{t}=Q_{m d} \times \text { faktor kebocoran air }
$$

dengan:

$Q_{m d} \quad=$ debit penggunaan air bersih $\left[\mathrm{m}^{3} / \mathrm{s}\right]$,

$P_{n} \quad=$ jumlah pelanggan PDAM,

$q=$ kebutuhan air per orang per hari [ $\mathrm{m}^{3} /$ hari/orang],

$f_{m d} \quad=$ angka faktor jam puncak,

$Q_{t} \quad=$ debit total produksi air bersih,

$f(\max$ day $)=$ angka faktor harian maksimum, 


\section{METODOLOGI}

\subsection{Skema Penelitian}

Urutan dan tahapan penelitian disajikan pada bagan alir Gambar 1.

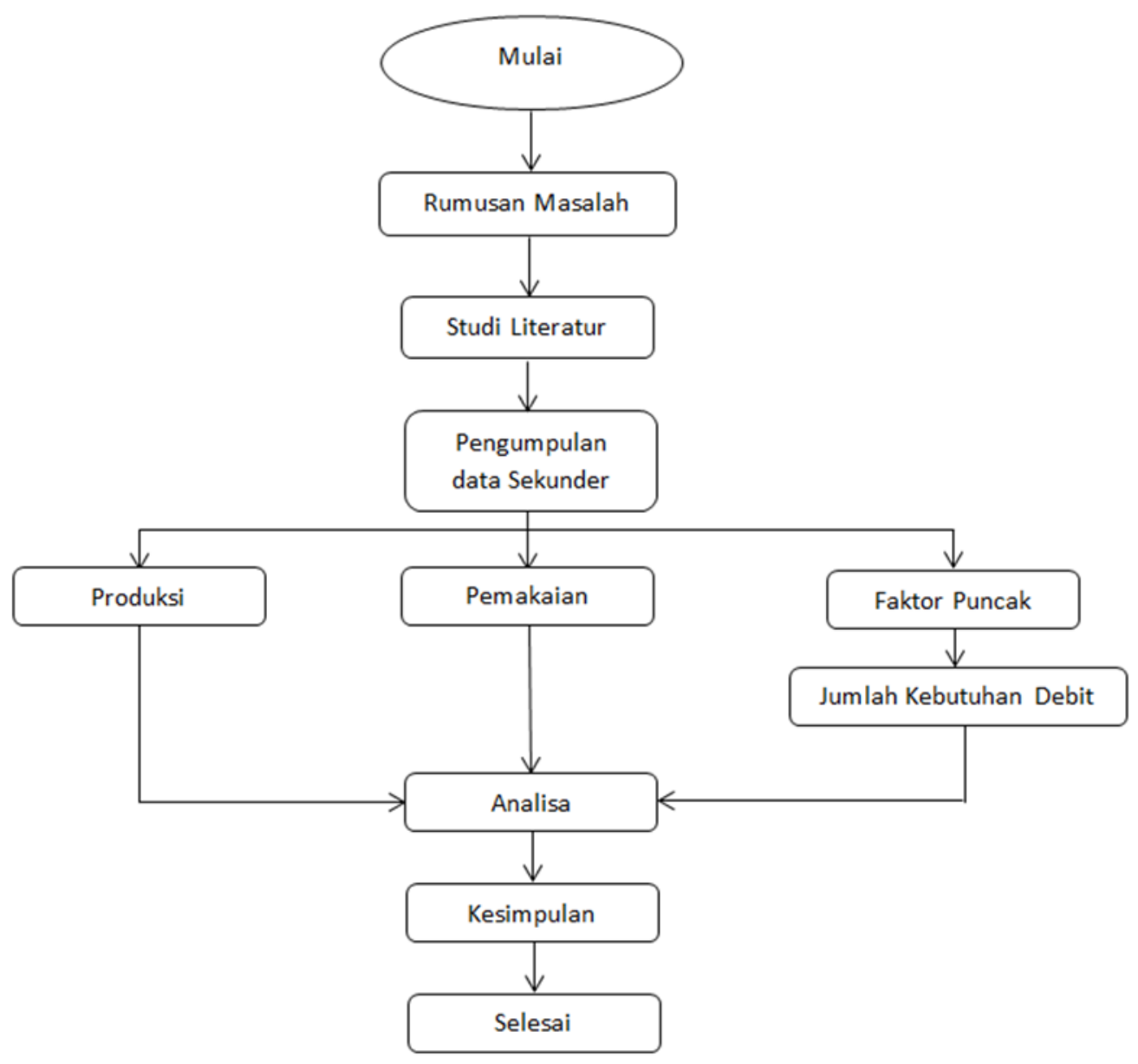

Gambar 1. Skema penelitian

PDAM Tirta Rangga yang terletak di Kecamatan Pabuaran. Secara administratif daerah penelitian terletak di Kecamatan Pabuaran, Kabupaten Subang, Jawa Barat. Data berupa debit produksi dan distribusi air harian dari PDAM Tirta Rangga sepanjang tahun 2019. Data debit tersebut kemudian dilakukan analisa pengambilan air metoda instan untuk mendapatkan data produksi atau distribusi air jam-jaman, baik untuk data pada musim kemarau maupun pada musim hujan. Penentuan faktor jam puncak dari tiap metosa perhitungan selanjutnya akan dibandingkan dengan nilai faktor jam puncak dari Dikrektorat Jenderal Cipta Karya. Jumlah produksi yang dibutuhkan penduduk Kecamatan Pabuaran ditentukan berdasarkan nilai faktor jam puncak dan jumlah penduduk Kecamatan Pabuaran. Volume perhitungan produksi air akan dibandingkan dengan ketersediaan air dari PDAM Tirta Rangga untuk menentukan kecukupan air bersih bagi penduduk Kecamatan Pabuaran.

\section{HASIL DAN PEMBAHASAN}

\subsection{Grafik Fluktuasi Debit Air PDAM Tirta Rangga pada Kecamatan Pabuaran} Produksi air pada musim hujan dan musim kemarau dapat dilihat pada Gambar $\mathbf{2}$ di bawah ini. 


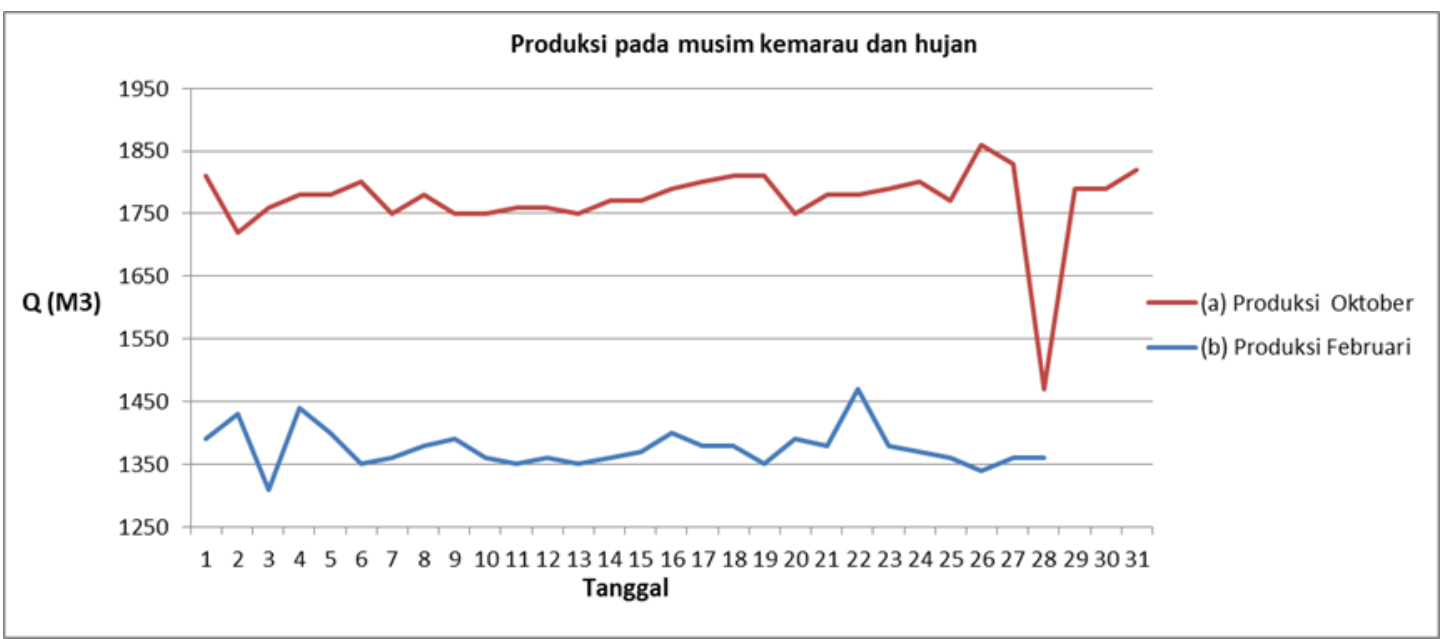

Gambar 2. Grafik pencatatan meter air pada musim kemarau dan musim hujan

Produksi air pada musim kemarau terjadi pada bulan Oktober 2019 terdapat pada Gambar 2, menunjukkan bahwa penggunaan air di PDAM Tirta Rangga Kecamatan Pabuaran lebih tinggi dibandingkan saat musim hujan, walaupun terjadi penurunan yang signifikan pada bulan Oktober tanggal 28. Hal itu disebabkan adanya perbaikan jaringan distribusi sehingga proses distribusi kepada konsumen berkurang bahkan terhambat. Produksi pada musim hujan diwakili grafik pada bulan Februari dengan produksi yang lebih rendah dibandingkan dengan musim kemarau. Penggunaan air yang tinggi pada musim kemarau disebabkan intensitas hujan sangat sedikit sehingga kadar air di dalam tanah sangat sedikit, suhu pada musim kemarau juga sangat tinggi sehingga kegiatan mandi, gelontor toilet dan konsumsi air minum juga tinggi.

\subsection{Penggunaan Air pada Jam Puncak dan Harian Maksimum}

Penggunaan air pada jam puncak sangat berkaitan dengan pola kegiatan penduduk dalam penggunaan air. Penggunaan air maksimum pada jam tertentu adalah debit yang akan digunakan untuk menentukan angka faktor harian maksimum. Angka faktor harian maksimum adalah debit maksimum yang dimanfaatkan untuk keperluan domestik pada hari-hari tertentu dalam satu minggu. Angka faktor jam puncak dan faktor harian maksimum sangat berperan dalam menetukan volume produksi PDAM. Volume yang didasarkan data sekunder untuk musim kemarau, diwakili bulan Oktober didapatkan nilai sebagai berikut:

$\begin{array}{lll}\text { - Volume maksimum Harian } & =1.860 & \mathrm{~m}^{3} \\ \text { - Volume rerata penggunaan air dalam satu minggu } & =1.771,935 & \mathrm{~m}^{3} \\ \text { - Volume rerata harian musim kemarau } & =74,354 & \mathrm{~m}^{3} \\ \text { - Volume pada jam puncak harian musim kemarau } & =225,183 & \mathrm{~m}^{3}\end{array}$

Data yang sama untuk musim hujan, diwakili bulan Februari adalah sebagai berikut:

- Volume maksimum harian $\quad=1.470 \quad \mathrm{~m}^{3}$

- Volume rerata penggunaan air dalam satu minggu $\quad=1.375,714 \mathrm{~m}^{3}$

- Volume rerata harian musim kemarau $\quad=54,288 \quad \mathrm{~m}^{3}$

- Volume pada jam puncak harian musim kemarau $\quad=147,316 \quad \mathrm{~m}^{3}$

Volume penggunaan air rata-rata dalam satu minggu dibagi jumlah jam dalam satu hari untuk penentuan angka faktor jam puncak. Penggunaan air pada jam puncak terjadi di pagi hari dengan rentang waktu dari jam 06.00 hingga jam 08.00. Penggunaan maksimum disebabkan oleh padatnya kegiatan yang memanfaatkan banyak air di pagi hari. Penggunaan air tiap jam dalam satu hari akan memiliki frekuensi tinggi pada jam - jam tertentu saja, bergantung pada 
kebiasaan setiap orang yang berbeda-beda. Secara rinci debit rata-rata penggunaan air dapat disajikan dalam grafik berikut:

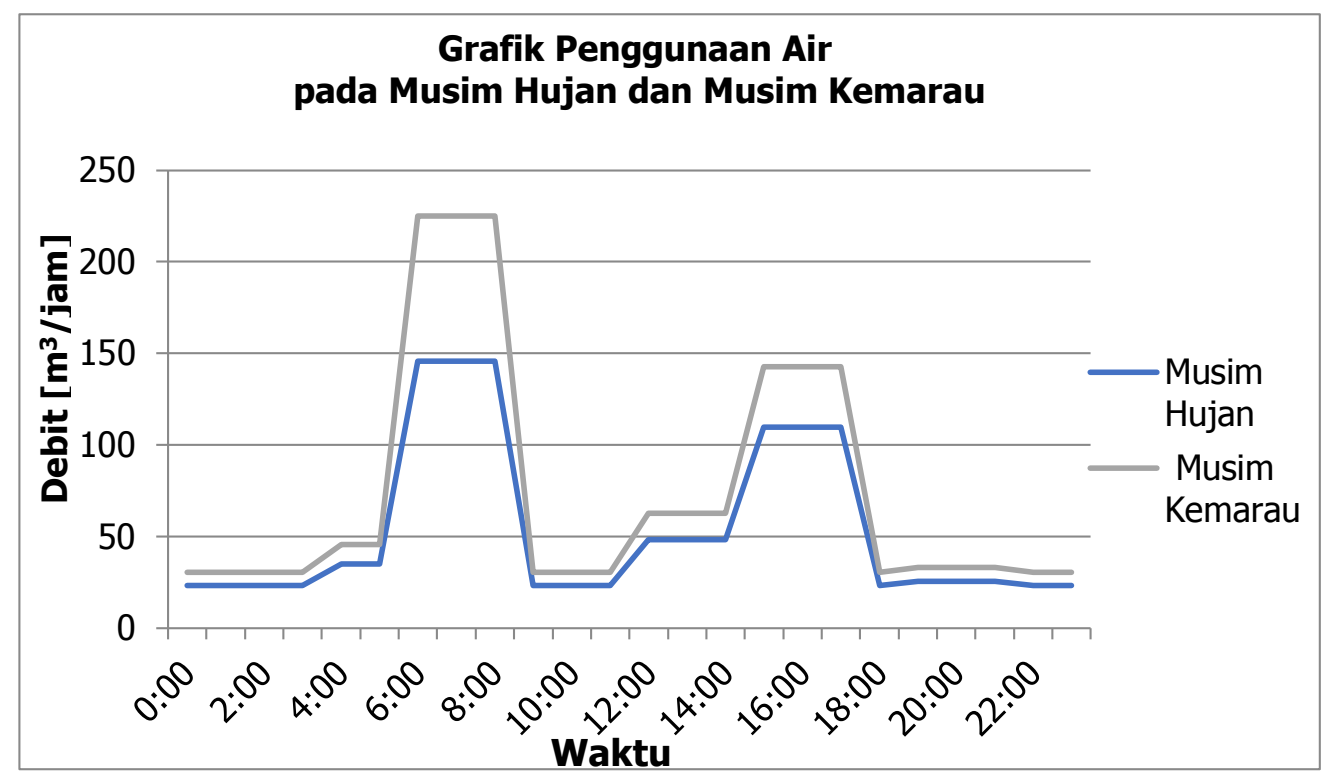

Gambar 3. Penggunaan air pada jam-jam tertentu

Gambar 3 menyajikan bahwa penggunaan air mulai meningkat pada jam 03.00 dimana diantaranya orang memulai kegiatan dengan berwudu dan gelontor toilet namun kegiatan seperti itu hanya sebagian kecil yg melakukannya. Penggunaan air terbanyak terjadi di pagi hari 06.00-08.00. Pada umumnya penggunaan air pada pagi hari meliputi kegiatan di dalam dan di luar rumah yang membutuhkan banyak air. Penggunaan air pada siang hari dengan frekuensi terbanyak terjadi pada jam 12.00-14.00 di antaranya adalah wudu, makan dan minum, dan penggunaan toilet. Penggunaan air di sore hari akan meningkat pada jam - jam setelah jam kerja berakhir karena banyak orang mulai melakukan aktivitas kembali di rumah masing - masing. Hal itu menunjukkan bahwa penggunaan air domestik sangat berpengaruh terhadap fluktuasi debit atau volume pemanfaatan air PDAM.

Data debit penggunaan air harian dan jam-jaman digunakan untuk menentukan angka faktor jam puncak dan angka faktor harian maksimum berdasarkan metode [9], baik pada musim kemarau maupun musim hujan adalah sebagai berikut:

Faktor harian maksimum $=\frac{\text { Harian maksimum }}{\text { Rata }- \text { rata penggunaan air }}$

Faktor harian maksimum musim kemarau $=\frac{1.860 \mathrm{~m}^{3} / \text { hari }}{1.771,935 \mathrm{~m}^{3} / \text { hari }}=1,050$

Faktor harian maksimum musim hujan $=\frac{1.470 \mathrm{~m}^{3} / \text { hari }}{1.375,714 \mathrm{~m}^{3} / \text { hari }}=1,131$

Faktor jam puncak $=\frac{\text { Jam puncak penggunaan harian }}{\text { Rata }- \text { rata penggunaan air }}$

Faktor jam puncak musim kemarau $=\frac{225,183 \mathrm{~m}^{3} / \text { hari }}{74,354 \mathrm{~m}^{3} / \text { hari }}=3,029$

RekaRacana - 220 
Faktor jam puncak musim hujan

$$
=\frac{147,316 \mathrm{~m}^{3} / \text { hari }}{54,288 \mathrm{~m}^{3} / \text { hari }}=2,714
$$

\subsection{Perhitungan Faktor Puncak}

Angka faktor jam puncak berdasarkan beberapa metode perhitungan faktor jam puncak disajikan pada Tabel 5 di bawah ini.

Tabel 5. Hasil Perhitungan Faktor Puncak

\begin{tabular}{lcc}
\hline \multicolumn{1}{c}{ Metoda Perhitungan Faktor Jam Puncak } & Faktor Jam Puncak & Faktor Puncak Harian \\
\hline Faktor puncak Red (1993) & 2,876 & 1,050 \\
\hline Faktor Puncak Diao dkk (2010) & 3,707 & 1,919 \\
\hline Faktor Puncak Briere (2007) & 2,850 & 1,900 \\
\hline Faktor Puncak Martinez-Solano (2008) & 2,347 & \\
\hline Faktor Puncak Tricarico (2007) & 1,706 & \\
\hline Faktor Puncak Dan Kebutuhan Air CPHEEO (1991) & 3,000 & 1,100 \\
\hline Faktor Puncak Dirtjen Cipta Karya (2000) & 1,500 & \\
\hline
\end{tabular}

Tabel 5 menyajikan beberapa nilai faktor jam puncak dari seluruh metoda yang dihitung dalam penelitian ini. Nilai faktor jam puncak dan faktor harian maksimum tersebut berguna untuk menentukan debit penggunaan air tertinggi pada jam-jam tertentu selama seminggu. Volume rata-rata penggunaan pada jam tersebut biasanya dikalikan dengan faktor jam puncak, sehingga akan diperoleh besarnya volume air yang harus disediakan pada jam puncak. Metode Red dengan faktor jam puncak 2,876 dan faktor puncak hariannya 1,050. Nilai faktor puncak harian metode Red merupakan nilai yang paling mendekati dengan ketetapan Dirjen Cipta Karya yaitu 1,5. Perhitungan faktor jam puncak berdasarkan rumus [3], dengan memasukan jumlah populasi, merupakan metoda yang menghasilkan angka faktor jam puncak tertinggi dibandingkan metoda yang lain, yaitu sebesar 3,707. Rumus [3] juga menghasilkan nilai faktor harian maksimum tertinggi dari pada metoda yang lainnya, sebesar 1,919. Perhitungan faktor jam puncak metode Tricarico (2007) didapatkan sebesar 1,706; lebih besar dari faktor jam puncak kriteria desain [4] sebesar 1,5 tetapi angka tersebut paling mendekati dibandingkan dengan hasil hitungan metoda yang lain. Adapaun perbedaan hasil dari metode lain, baik hasil hitungan faktor jam puncak maupun faktor harian maksimum, disebabkan oleh perbedaan iklim dan musim di daerah yang ditinjau, perbedaan kebiasaan dalam penggunaan air di tiap-tiap musim dan wilayah, ketersediaan air bersih (ketahanan air suatu daerah) serta harga ekonomi air. Perbedaan nilai-nilai faktor jam puncak disebabkan beberapa daerah seringkali memiliki metodenya sendiri untuk memperkirakan permintaan puncak dalam sistem mereka. Perhitungan metode hitungan faktor jam puncak dengan metode Red adalah pilihan yang tepat karena dapat mengakomodir perhitungan yang bervariasi terhadap perubahan penggunaan air oleh konsumen, baik dari variasi lokasi maupun waktu penelitian.

\subsection{Perhitungan kebutuhan debit}

Jumlah konsumen pelanggan PDAM Tirta Rangga sebanyak 12.430 jiwa. Perhitungan produksi air berdasarkan jumlah penduduk dan penggunaan air sebesar 80 liter/hari/diperoleh data sebagai berikut. 
Fransiska Yustiana, Wahdan Nurfa Afani Maulana

Tabel 6. Perhitungan Volume Air PDAM

\begin{tabular}{lccc} 
& Faktor Puncak Harian & $\begin{array}{c}\text { Kebutuhan Air Bersih } \\
{\left[\mathbf{m}^{3}\right]}\end{array}$ & $\begin{array}{c}\text { Volume Total } \\
{\left[\mathbf{m}^{3}\right]}\end{array}$ \\
\hline Metode Red (1993) & 1,050 & $1.043,822$ & $1.778,231$ \\
\hline Metode Diao, et al. (2010) & 1,919 & $1.908,629$ & $3.251,497$ \\
\hline $\begin{array}{l}\text { Metode Briere (2007) } \\
\text { Faktor Puncak Martinez- }\end{array}$ & 1,900 & $1.889,360$ & $3.218,671$ \\
\hline $\begin{array}{l}\text { Solano (2008) } \\
\text { Faktor Puncak Tricarico }\end{array}$ & 2,347 & $2.333,857$ & $3.975,906$ \\
\hline $\begin{array}{l}\text { Faktor Puncak dan } \\
\text { Kebutuhan Air CPHEEO } \\
(1991)\end{array}$ & 1,706 & $1.696,446$ & $2.890,028$ \\
\hline $\begin{array}{l}\text { Faktor Puncak Dirtjen Cipta } \\
\text { Karya (2000) }\end{array}$ & 3,000 & $2.983,200$ & $5.082,112$ \\
\hline
\end{tabular}

Hasil perhitungan volume total air PDAM Kecamatan Pabuaran pada tahun 2019 terdapat pada Tabel 6. Volume total dapat dihitung berdasarkan jumlah populasi dan jumlah kebutuhan air dikalikan dengan faktor kebocoran. Nilai kebocoran pada bulan Oktober 2019 PDAM Tirtarangga sebesar $41,3 \%$ pada saat pendistribusian air kepada konsumen angka ini lebih besar dari kriteria desain Direktorat Jenderal Cipta Karya yaitu 20\% - 30\%. Nilai harian maksimum terdapat pada hari sabtu tanggal 26 oktober 2019 sebesar $1.860 \mathrm{~m}^{3}$ per hari perhitungan kebutuhan nilai total kebutuhan air yang mendekati adalah dengan menggunakan perhitungan metode faktor puncak Metode [9] dengan nilai $1.778,231 \mathrm{~m}^{3}$ dengan faktor puncak harian sebesar 1,05 masih dibawah nilai Harian maksimum yang terjadi pada PDAM Tirta Rangga Bila mengggunakan kriteria desain yang diterbitkan oleh Direktorat Jenderal Cipta Karya. Faktor puncak harian sebesar 1,1 menghasilkan total produksi air harian sebesar $1.863,441 \mathrm{~m}^{3}$ mendekati perhitungan dengan memakai faktor puncak yang disyaratkan oleh Dirjen Cipta Karya, dengan kata lain perencanaan produksi air PDAM Tirta Rangga sudah sesuai aturan faktor jam puncak dari Dirjen Cipta Karya.

\section{KESIMPULAN DAN SARAN}

\subsection{Kesimpulan}

Dari hasil pembahasan dapat disimpulkan sebagai berikut:

1. Produksi air di PDAM Tirta Rangga berdasarkan jumlah konsumen dan penggunaan air 80 liter/hari/orang ini telah sesuai dengan kriteria desain Direktorat Jenderal Cipta Karya.

2. Penggunaan air jam puncak pada musim kemarau sebesar $225,183 \mathrm{~m}^{3} /$ hari tertinggi di bulan Oktober dan pada musim hujan sebesar 147,316 $\mathrm{m}^{3} /$ hari terendah di bulan Februari yang terjadi saat pagi hari yaitu jam 06.00 sampai dengan 08.00 WIB, sedangkan penggunaan air maksimum pada musim kemarau sebesar $1.860 \mathrm{~m}^{3} /$ hari dan musim hujan sebesar $1.470 \mathrm{~m}^{3} /$ hari.

3. Faktor puncak harian yang disyaratkan oleh Direktorat Jenderal Cipta Karya sebesar 1,1 dan perhitungan debit produksi total diperoleh nilai sebesar $1.863,441 \mathrm{~m}^{3}$. Nilai debit produksi PDAM Tirta Rangga sudah memenuhi angka yang ditetapkan dari debit yang terjadi di lapangan yaitu sebesar $1.860 \mathrm{~m}^{3} /$ hari dan memenuhi desain kriteria perencanaan yang dikeluarkan oleh Direktorat Jenderal Cipta Karya.

4. Pencarian faktor puncak beberapa metode yang paling mendekati pada acuan yang dikeluarkan oleh Direktorat Jenderal Cipta Karya sebesar 1,1 faktor harian maksimum dan 1,5 untuk faktor jam puncak; adalah hasil perhitungan faktor harian maksimum dengan metode [9] dengan nilai hasil perhitungan 1,05 dan untuk faktor jam puncak yang mendekati adalah metode perhitungan Tricarico (2007) dengan hasil perhitungan 1,706. 


\section{Perbandingan Metode Perhitungan Faktor Jam Puncak PDAM Tirta Rangga \\ di Kecamatan Pabuaran - Kabupaten Subang}

\subsection{Saran}

Dari hasil pembahasan dapat disarankan sebagai berikut:

1. Perencanaan volume ketersediaan air dan jaringan distribusi pada PDAM di Kecamatan Pabuaran sudah tepat dan sesuai standar yang telah ditetapkan oleh Dirjen Cipta Karya.

2. Perlu dilakukan penelitian yang membahas kondisi sosial dan ekonomi masyarakat terhadap merupakan faktor penentu pola penggunaan air domestik, terutama pemanfaatan air pada jam-jam puncak.

\section{DAFTAR PUSTAKA}

[1] Brière, F.G. (2007). Drinking-water distribution, sewage, and rainfall collection. Montréal, Canada: Presses Internationales Polytechnique.

[2] CPHEEO. (1991). Manual on Water Supply and Treatment. India: Ministry of Urban development, Government of India.

[3] Diao, K., Barjenbruch, M. and Bracklow, U. (2010). Study on the impacts of peaking faktors on a water distribution system in Germany. Water Science and Technology: Water Supply, 10(2), pp. 165-172.

[4] Direktorat Jenderal Cipta Karya Departemen Pekerjaan Umum. (2007). Buku Panduan Pengembangan Air Minum. Jakarta: Direktorat Jenderal Cipta Karya Departemen Pekerjaan Umum.

[5] Fair, G.M., Geyer, J.C., \& Okun, D.A. (1971). Elements of Water Supply and Wastewater Disposal Second Edition. New York: John Wiley \& Sons, Inc. and Toppan Company, Ltd.

[6] Leeden, V.D.F., Troise, F.L., \& Todd, D.K. (1990). The Water Encyclopedia Second Edition. USA: Lewis Publishers, Inc.

[7] Martínez-Solano, J., Iglesias-Rey, P.L., Pérez-García, R., \& López-Jiménez, P.A. (2008). Hydraulic analysis of peak demand in looped water distribution systems. Journal of Water Resources Planning and Management, 134(6), pp. 504-510.

[8] Poedjiastoeti, H. (2021). Pengaruh kondisi sosial ekonomi masyarakat terhadap pola penggunaan air domestik. Jurnal Lingkungan Sultan Agung, 1(1), pp. 64-77.

[9] Red, T. 1993. Analisa Faktor Jam Puncak dan Maksimum Harian. Jurnal Air Minum, 65(_), pp. 19-23.

[10] Scheepers, H.M. (2012). Deriving peak faktors for residential indoor water demand by means of a probability based end-use model. Doctoral dissertation. Stellenbosch: Stellenbosch University.

[11] Syahputra, B. (2020). Penentuan Faktor Jam Puncak dan Harian Maksimum Terhadap Pola Penggunaan Air Domestik Di Kecamatan Kalasan, Sleman, Yogyakarta. Jurnal Lingkungan Sultan Agung, 1(1), pp. 1-15. 